\title{
The effect of post-wash total progressive motile sperm count and semen volume on pregnancy outcomes in intrauterine insemination cycles: a retrospective study
}

\author{
intrauterin inseminasyon sikluslarinda yıkama sonrası total progresif motil sperm \\ sayısı ve semen volümünün gebelik sonuçlarına etkisi: Retrospektif bir çalışma
}

\author{
Elvan Koyun Ok, Ömer Erbil Doğan, Recep Emre Okyay, Bülent Gülekli \\ Division of Reproductive Medicine, Department of Obstetrics And Gynecology, Dokuz Eylül University Medical Faculty, \\ izmir, Turkey
}

\section{Abstract}

Objective: The purpose of this study was to determine the impact of post-wash total progressive motile sperm count (TPMSC) and semen volume on pregnancy outcomes in intrauterine insemination (IUI) cycles.

Material and Methods: The retrospective study included a total of 156 cycles (141 couples) and was performed in our center over a 24-month period. The semen parameters were recorded for each man and each insemination. The semen samples were re-evaluated after the preparation process. Post-wash TPMSC values were divided into four groups; Group 1: $<1 \times 10^{6}$; Group 2: $1-4.9 \times 10^{6}$; Group 3: $5-9.9 \times 10^{6}$; Group 4: $10 \times 10^{6}$ and $>10 \times 10^{6}$. Post-wash inseminated semen volume was divided into three groups; Group 1: $0.3 \mathrm{~mL}$; Group 2: $0.4 \mathrm{~mL}$; Group 3: $0.5 \mathrm{~mL}$. The effect of post-wash total progressive motile sperm and semen volume on pregnancy outcomes was evaluated.

Results: The pregnancy rates per cycle and per couple were $27.56 \%$ and $30.49 \%$, respectively. There was not a significant relationship between the inseminated semen volume and pregnancy rate $(p>0.05)$. However, a significant linear-by-linear association was documented between the TPMSC and pregnancy rate $(\mathrm{p}=0.042)$.

Conclusion: Our findings suggest that the post-wash inseminated semen volume should be between $0.3-0.5 \mathrm{~mL}$. An average post-wash total motile sperm count of $10 \times 10^{6}$ may be a useful threshold value for IUI success, but more studies are needed to determine a cut-off value for TPMSC. (J Turkish-German Gynecol Assoc 2013; 14: 142-5)

Key words: Intrauterine insemination, post-wash total progressive motile sperm count, post-wash semen volume, pregnancy

Received: 24 May, 2013

Accepted: 02 July, 2013
Özet

Amaç: Bu çalışmada intrauterin inseminasyon sikluslarında yıkama sonrası motil sperm sayısı ve semen volümünün gebelik sonuçlarına etkisini araştırmak hedeflenmiştir.

Gereç ve Yöntemler: Retrospektif olan çalışma, 24 aylık periyodda merkezimize başvuran toplam 156 siklusu (141 çift) kapsamaktadır. Her inseminasyonda semen parametreleri kaydedildi. Semen örnekleri yıkama sonrası tekrar değerlendirildi. Yıkama sonrası total progresif motil sperm sayısı dört gruba ayrıldı; Grup 1: $<1 \times 10^{6}$; Grup 2:

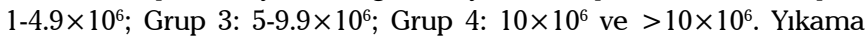
sonrası insemine edilen semen volumü ise üç gruba ayrıldı; Grup 1: $0.3 \mathrm{~mL}$; Grup 2: $0.4 \mathrm{~mL}$; Grup 3: $0.5 \mathrm{~mL}$. Ylkama sonrası total progresif motil sperm sayısının ve insemine edilen semen volumünün gebelik oranlarına etkisine bakıldı.

Bulgular: Siklus ve çift başına gebelik oranlanı sırasıyla \%27.56 ve \%30.49 olarak saptandı. İnsemine edilen semen volümü ile gebelik oranı arasında anlamlı bir ilişki saptanmadı. ( $>>0.05)$ Ancak total progresif motil sperm sayısı ile gebelik oranı arasında "lineer by lineer ilişki" saptandı. $(\mathrm{p}=0.042)$.

Sonuç: Bulgularımız yıkama sonrası semen volümünün $0.3-0.5 \mathrm{~mL}$ arasında olabileceğini desteklemektedir. Yıkama sonrası total motil sperm sayısının en az $10 \times 10^{6}$ olması intrauterine inseminasyon başarısı için sınır değer olabilir. Ancak total progresif motil sperm sayısını sınır değer olarak kabul edebilmek için daha fazla çalışmaya gereksinim vardır. (J Turkish-German Gynecol Assoc 2013; 14: 142-5)

Anahtar kelimeler: Intrauterin inseminasyon, ylkama sonrası total progresif sperm sayısı, yıkama sonrası semen volümü, gebelik

Geliş Tarihi: 24 Mayıs 2013

Kabul Tarihi: 02 Temmuz 2013

\section{Introduction}

Intrauterine insemination (IUI) is a method that has been used for many years in the treatment of infertile couples. IUI is the first referenced assisted reproductive technique in mild to moderate male infertility. IUI is non-invasive, very simple and less expensive than classical in vitro fertilization and intracytoplasmic sperm injection (ICSI).

IUI success depends on many factors such as drugs, the timing and number of cycles and total motile sperm count after washing. Another important factor affecting the success of IUI is the number of motile sperm inserted into the uterus (1). 
Most studies have suggested that the success of IUI, and therefore pregnancy rates, decrease if there is not a sufficient number of motile sperm after washing (2-5).

Semen analysis is the first step to accurately diagnose male infertility. Sperm count, sperm motility and the percentage of sperm with normal morphology are the main criteria for the quality of semen. When determining sperm quality, the values established by the World Health Organization (WHO) 2010 are often used (6). However, the cut-off values for TPMSC (total motile progressive sperm count) are still controversial and vary between $0.3 \times 10^{6}$ and $20 \times 10^{6}(7)$. Total progressively motile sperm is defined as the product of total sperm count and percent progressive motility.

The purpose of this study was to investigate the effect of postwash TPMSC and semen volume on pregnancy outcomes in intrauterine insemination cycles.

\section{Materials and Methods}

This retrospective study included a total of 156 cycles (141 couples) and was performed in our center over a 24-month period (July 2009 to July 2011). These couples were candidates for IUI because of mild male factor infertility or unexplained infertility. Men with mild male factor infertility had semen analysis where only one of the sperm parameters was below the normal range (6).

All the IUI cycles underwent controlled ovarian stimulation with gonadotrophins. The stimulation treatment was started on the second day of the cycle and was continued until ovulation or observation of an initial rise in luteinizing hormone (LH). Recombinant follicle stimulating hormone (FSH) (Gonal-F; Ares-Serono, Geneva, Switzerland; or Puregon, Organon International Inc., Roseland, NJ, USA) was used. The starting gonadotrophins dosage (37.5-100 IU/day) was adjusted according to the hormone profile, age and infertility duration. The initial dose was continued for six days and organized according to the ovarian response.

Female serum hormone levels (estradiol-17b and LH) were measured and vaginal ultrasonography was performed to assess the size and number of follicles and endometrial maturation. This evaluation was begun on the seventh day and the evaluation was repeated after two or three days, depending on follicular development. Ovulation triggering was achieved by subcutaneous injection of $250 \mu \mathrm{g}$ of recombinant human chorionic gonadotrophin (hCG; Ovitrelle, Ares-Serono). Insemination was performed 36 hours after the hCG injection. A single dose of recombinant hCG (10000 IU) was given when the mean diameter of the leading follicle reached $\geq 18 \mathrm{~mm}$. The husband was instructed to abstain from sexual intercourse for 3-5 days before insemination. Semen samples were obtained by masturbation in sterile plastic containers. After liquefaction of the semen (about 30 minutes at room temperature), the initial semen volume, sperm count and progressive motility were evaluated according to WHO criteria. Semen samples were processed using a density gradient (PureSperm ${ }^{\circledR}$, Nidacon International AB, Sweden) and sperm wash medium (Sperm Wash, Nidacon, International AB, Sweden). PureSperm gradients $90 \%$ and $50 \%$ were used for the experiment. All procedures were conducted under sterile conditions. Media were brought to $37^{\circ} \mathrm{C}$. Using a sterile pipette, $1 \mathrm{~mL}$ of the lower layer (90\% PureSperm gradient) was transferred into a conical centrifuge tube. Using a new sterile pipette, $1 \mathrm{~mL}$ of the upper layer (50\% PureSperm gradient) was gently dispensed on top of the lower layer. A liquefied semen sample was then placed on top of the upper layer and the tube was centrifuged for 15 minutes at $1800 \mathrm{rpm}$. The upper and lower layers were carefully aspirated without disturbing the pellet. Using a transfer pipette, $4 \mathrm{~mL}$ of sperm wash medium was added and the re-suspended pellet was centrifuged for 5 minutes at $1500 \mathrm{rpm}$. The supernatant was then removed and 0.3-0.5 $\mathrm{mL}$ of sperm wash medium was gently dispensed on the top of the pellet. The tube was then incubated at an angle of $45^{\circ}$ for $30-60$ minutes in the incubator at $37^{\circ} \mathrm{C}$ and $5 \% \mathrm{CO}_{2}$. After the incubation period, the entire supernatant was transferred into a $5 \mathrm{~mL}$ tube. IUI was performed using a catheter (Gynetics Medical Products N.V. Hamont-Achel, Belgium) through the cervix and injecting washed sperm directly into the uterus. Total motile sperm count and post-wash motile sperm count were calculated by the formula (volume $\mathrm{x}$ motile sperm count $\mathrm{x}$ motility).

Post-wash TPMSC was divided into four groups; Group 1:

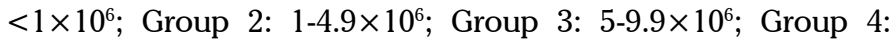
$10 \times 10^{6}$ and $>10 \times 10^{6}$. Post-wash inseminated semen volume was divided into three groups; Group 1: $0.3 \mathrm{~mL}$; Group 2: 0.4 $\mathrm{mL}$; Group 3: $0.5 \mathrm{~mL}$.

Serum hCG levels were determined two weeks after hCG injection in the absence of menstruation for a diagnosis of pregnancy. A clinical pregnancy was defined as serum positive $\beta$-hCG. Statistical analysis of the data was done using SPSS software (version 16, SPSS, Chicago, USA). The data were analyzed using the independent t-test and the $\mathrm{x}^{2}$ test. Significance was set at $\mathrm{p}<0.05$.

\section{Results}

The median age of the women was 30 years (39-42) while that of the males was 33 years (23-65) at the time of IUI. Pregnancy rates per cycle and per couple were $27.56 \%$ and $30.49 \%$, respectively. Baseline characteristics in the pregnant and nonpregnant groups are shown in Table 1.

A comparison of the sperm parameters in the pregnant (41 single pregnancies, 2 twin pregnancies) and non-pregnant groups are summarized in Tables 2 and 3.

Table 1. Baseline characteristics in the pregnant and nonpregnant groups

\begin{tabular}{|l|c|c|c|}
\hline & pregnant & non-pregnant & \multirow{2}{*}{ p value } \\
\cline { 2 - 3 } & n (range) * & n (range) * & p \\
\hline Woman's age (y) & $30(21-40)$ & $31(19-42)$ & 0.75 \\
\hline Man's age (y) & $32(23-41)$ & $33(25-65)$ & 0.12 \\
\hline Infertility duration (y) & $2.5(1-6)$ & $3(1-7)$ & 0.40 \\
\hline *Data are presented as median (min-max) \\
\hline
\end{tabular}


When the TPMSC was $\geq 10 \times 10^{6}$, the pregnancy rate was higher than in the groups with TPMSC $<1 \times 10^{6}, 1-4.9 \times 10^{6}$ and $5-9.9 \times 10^{6}$ (40.30\%, 27.20\%, 19.60\% and 21.40\%, respectively (Tables 3 and 4). A "linear by linear" association was found between post-wash

Table 2. Sperm parameters in the pregnant and non-pregnant groups

\begin{tabular}{|l|c|c|c|}
\hline \multirow{2}{*}{ Pre-wash } & pregnant & non-pregnant & \\
\cline { 2 - 3 } & n (IQR) & n (IQR) & p value \\
\hline Semen volume (mL) & $2(1)$ & $3(2)$ & 0.38 \\
\hline Sperm count $\left(10^{6} / \mathrm{mL}\right)$ & $44(47)$ & $44(44.5)$ & 0.65 \\
\hline Progressive motility (\%) & $36(20)$ & $40(20.5)$ & 0.05 \\
\hline TPMSC $\left(10^{6}\right)$ & $40(48)$ & $60(74)$ & 0.01 \\
\hline Post-wash & $0.4(0.2)$ & $0.3(0.2)$ & 0.66 \\
\hline Semen volume (mL) & $24(35)$ & $15(22)$ & 0.65 \\
\hline Sperm count $\left(10^{6} / \mathrm{mL}\right)$ & $100(0)$ & $100(0)$ & - \\
\hline Progressive motility (\%) & $9(11)$ & $6(7.5)$ & 0.59 \\
\hline TPMSC (10 $)$ & *Data are presented as the median, IQR: interquartile range \\
\hline
\end{tabular}

Table 3. Comparison of sperm parameters (post-wash TPMSC and semen volume) between groups

\begin{tabular}{|l|c|c|c|}
\hline \multirow{2}{*}{$\begin{array}{l}\text { Post-wash } \\
\text { TPMSC (x106) }\end{array}$} & pregnant & non-pregnant & \multirow{2}{*}{} \\
\cline { 2 - 3 } & $\mathbf{n}(\%)$ & $\mathbf{n}(\%)$ & p value \\
\hline$<1$ & $3(7)$ & $8(7.1)$ & 0.08 \\
\hline $1-4.9$ & $10(23.30)$ & $41(36.3)$ & 0.00 \\
\hline $5-9.9$ & $9(20.90)$ & $33(29.2)$ & 0.001 \\
\hline 10 and $>10$ & $21(48.80)$ & $31(27.4)$ & 0.16 \\
\hline $\begin{array}{l}\text { Post-wash } \\
\text { semen volume (mL) }\end{array}$ & $\mathbf{n}(\mathbf{\%})$ & $\mathbf{n}(\mathbf{\% )}$ & p value \\
\hline 0.3 & $20(46.5)$ & $61(54)$ & 0.00 \\
\hline 0.4 & $6(14)$ & $11(9.7)$ & 0.22 \\
\hline 0.5 & $17(39.5)$ & $41(36.3)$ & 0.002 \\
\hline * Parentheses indicate percentages & \\
\hline
\end{tabular}

TPMSC and the pregnancy rate $(\mathrm{p}=0.042)$. On the other hand, no significant relationship was found between the post-wash inseminated semen volume $(0.3,0.4$ or $0.5 \mathrm{~mL})$ and the pregnancy rate $(\mathrm{p}>0.05)$ (Table 4$)$.

\section{Discussion}

It is known that semen parameters affect IUI success. Although the World Health Organization's (WHO) reference values for semen analysis are commonly used to assess sperm quality, predictive sperm parameters and threshold values with respect to semen characteristics for successful IUI are still controversial (1). The post-wash inseminated sperm count is considered to be an important prognostic factor (2). In different studies, the cut-off values for the post-wash TPMSC have varied between $0.3 \times 10^{6}$ and $20 \times 10^{6}$ (7). This difference could be based on sperm preparation techniques (swim-up or density gradient wash).

In this study, the pregnancy rate per cycle was 27.56. Baseline characteristics in pregnant and non-pregnant groups were homogeneous (Table 1). Most studies have reported very low pregnancy rates in groups in which the post-wash TPMSC was $<1 \times 10^{6}(3)$. In our study, the pregnancy rate for this group was $1.92 \%$ (Table 3 ).

A "linear by linear" association was found between post-wash TPMSC and the pregnancy rate $(\mathrm{p}=0.042)$. For the post-wash TPMSC, a lower value of $10 \times 10^{6}$ could be a criterion for IUI success. However, more studies are needed to determine a threshold value for post-wash TPMSC.

Some studies have shown conflicting results when IUI techniques were compared, also in terms of the volume of material deposited in the fundus region of the uterus during the procedure (8-10). Franco Junior et al. (10) evaluated the volume of material deposited during IUI and the site involved by hysterosalpingography and noted that, starting from $0.4 \mathrm{~mL}$, the contrast dye reached the uterus, isthmus and tube ampulla, whereas a volume of $0.2 \mathrm{~mL}$ did not reach the tube.

Do Amaral et al. (11) performed 164 cycles of ovulation induction followed by IUI. The patients were divided into two groups according to the technique used. The low volume

Table 4. Pregnancy rates, post-wash total progressive sperm counts and semen volumes

\begin{tabular}{|l|c|c|c|c|c|}
\hline & Group 1 & Group 2 & Group 3 & Group 4 & Total \\
\hline Post-wash TPMSC $\left(\times 10_{6}\right)$ & $<1$ & $1-4.9$ & $5-9.9$ & 10 and >10 & 156 \\
\hline Cycles (n) & 11 & 51 & 42 & 52 & 43 \\
\hline Pregnancies (n) & 3 & 10 & 9 & 21 & 27.56 \\
\hline Pregnancies per cycle (\%) & 27.20 & 19.60 & 21.40 & 40.30 & \\
\hline \multicolumn{2}{|l|}{ Group 1 } & Group 2 & Group 3 & & 156 \\
\hline Post-wash semen volume (mL) & 0.3 & 0.4 & 0.5 & & 43 \\
\hline Cycles (n) & 81 & 17 & 58 & & 27.56 \\
\hline Pregnancies (n) & 20 & 6 & 17 & & \\
\hline Pregnancies per cycle (\%) & 24.69 & 35.20 & 29.30 & & \\
\hline TPMSC: total progressive motile sperm count
\end{tabular}


group included 50 cycles and $0.5 \mathrm{~mL}$ of inseminated semen with the high volume group included 114 cycles and $3.0 \mathrm{~mL}$ of inseminated semen. They obtained a similar clinical pregnancy rate for the two groups $(14.0 \%$ for the low volume group and $15.7 \%$ for the high volume group).

We wanted to investigate the effect of low volumes of inseminated sperm on pregnancy outcomes. When we compared the results of IUI with the volumes $0.3-0.4 \mathrm{~mL}$ and $0.5 \mathrm{~mL}$, we detected no advantages. In our study, no significant relationship was found between post-wash inseminated semen volume $(0.3,0.4$ or $0.5 \mathrm{~mL})$ and the pregnancy rate $(\mathrm{p}>0.05)$. Our findings support the notion that post-wash inseminated semen volume can be from 0.3 to $0.5 \mathrm{~mL}$. There are no detailed studies in the literature on this subject.

The lack of analysis regarding sperm morphology and the retrospective nature of the study are the weaknesses of this study. In the next step, our aim is to plan a prospective study including more patients with an assessment of sperm morphology.

Ethics Committee Approval: Ethics commitee approval was received for this study.

Informed Consent: Written informed consent was obtained from patients who participated in this study.

Peer-review: Externally peer-reviewed.

Author contributions: Concept - E.K., Ö.E.D.; Design - E.K.; Supervision-E.K.; Resource-E.K., Ö.E.D., R.E.O., B.G.; Materials - E.K., Ö.E.D., R.E.O., B.G.; Data Collection\&/or Processing E.K., Ö.E.D., R.E.O., B.G.; Analysis\&/or Interpretation - E.K.; Literature Search - E.K.; Writing - E.K.; Critical Reviews - E.K.

Conflict of Interest: No conflict of interest was declared by the authors.

Financial Disclosure: No financial disclosure was declared by the authors.

\section{References}

1. Iltemir Duvan C, Berker B, Bayrak O, Aydos K, Ozturk Turhan N, Satiroglu H. Comparison of semen parameters between pregnant and non-pregnant couples with male factor infertility during intrauterine insemination. Turk J Med Sci 2009; 39: 531-6.

2. Kılıcdag EB, Bagis T, Haydardedeoglu B, Tarim E, Aslan E, Erkanli S, et al. The Prognostic Factors that Could be Effect Pregnancy Rates in Intra Uterine Insemination (IUI) Cycles. TJOD 2005; 2: 223-8.

3. Nikbakht R, Saharkhiz N. The Influence of sperm morphology, total motile sperm count of semen and the number of motile sperm inseminated in sperm samples on the success of intrauterine insemination. UFS 2011; 5: 168-73.

4. Alici B, Ozkara H, Onal B, Akkus E, Hattat H. The effect of total motile sperm count to the success of intrauterine insemination. Cerrahpaşa J Med 2000; 31: 61-5.

5. Miller DC, Hollenbeck BK, Smith GD, Randolph JF, Christman GM, Smith YR, et al. Processed total motile sperm count correlates with pregnancy outcome after intrauterine insemination. Urology 2002; 60: 497-501. [CrossRef]

6. World Health Organization, Department of Reproductive Health and Research. WHO laboratory manual for the examination and processing of human semen, Switzerland, WHO Press, 2010.

7. Van Weert J-M, Repping S, Von Voorhis BJ, Bossuyt PMM, Mol BWJ. Performance of the post-wash total motile sperm count as a predictor of pregnancy at the time of intrauterine insemination: a meta-analysis. Fertil Steril 2004; 82: 612-20. [CrossRef]

8. Fanchin R, Olivennes F, Righini C, Hazont A, Schwab B, Frydman R. A new system for fallopian tube sperm perfusion leads to pregnancy rates twice as high as standard uterine insemination. Fertil Steril 1995; 54: 505-10.

9. Galle PC, McRae MA, Colliver JA, Alexander JS. Sperm washing and intrauterine insemination for cervical factor, oligospermia, immunologic infertility and unexplained infertility. J Reprod Med 1990; 35: 116-22.

10. Franco Junior JG, Baruffi RLR, Mauri AL, Stone SC. Radiologic evaluation of incremental intrauterine instillation of contrast material. Fertil Steril 1992; 58: 1065-7.

11. Do Amaral VF, Ferriani RA, Dos Reis RM, De Sala MM, De Moura MD. Effect of inseminated volume on intrauterine insemination. $\mathrm{J}$ Assist Reprod Genet 2001; 18: 413-6. [CrossRef] 